\title{
Determinants of the presence of conflict bird and mammal species at pond fisheries in western Poland
}

\author{
Brygida Manikowska-Ślepowrońska • Barbara Szydzik • \\ Dariusz Jakubas
}

Received: 27 July 2015/Accepted: 5 November 2015/Published online: 13 November 2015

(C) Springer Science+Business Media Dordrecht 2015

\begin{abstract}
The presence of piscivorous vertebrates at fish farms often ignites conflicts over fish resources managed by humans. This study investigates the factors affecting the presence of conflict vertebrates at fish ponds. A telephone survey in western Poland in 2012-2013 examined 104 fish ponds. Six species were most often observed at fish farms: European otter Lutra lutra (87\% at farms), grey heron Ardea cinerea (83\%), great cormorant Phalacrocorax carbo (67\%), great egret Ardea alba (42\%), Eurasian beaver Castor fiber (37\%) and American mink Neovison vison (31\%). American mink, Eurasian beaver, great egret and grey heron were more often present at carp ponds. Eurasian beaver, European otter and great cormorant were present more often at larger ponds. Latitude significantly affected the occurrence of great egrets (more frequent in the south). European otter and American mink were present more often at ponds supplied by river water. Ponds supplied by river water may provide both species opportunity to enter imperceptibly to farms, with no need to exit water. Methods of pond protection and proximity of buildings to farms
\end{abstract}

Handling Editor: Thomas Mehner

B. Manikowska-Ślepowrońska ( $₫)$.

B. Szydzik · D. Jakubas

Department of Vertebrate Ecology and Zoology,

University of Gdańsk, ul. Wita Stwosza 59,

80-308 Gdańsk, Poland

e-mail: BrygidaMS@wp.pl did not significantly affect the presence of conflict species. The data from this study concerning the presence of piscivores at ponds may serve as base for more comprehensive studies investigating the impact of these species on fish farming practices as well as for comparative and experimental studies on the effectiveness of various mitigation measures. Regular surveys of species occurring at ponds may be a tool of monitoring invasive species as well as species increasing its range.

Keywords Human-wildlife conflict - Waterbirds . Piscivores $\cdot$ Fish farming

\section{Introduction}

Aquaculture is attractive to piscivorous animals due to high fish density, shallow water and similar size prey providing them easy access to food (Littauer 1990; Curtis et al. 1996; IUCN 1997). In addition, hatchery fish may not develop the full potential for antipredatory behaviour as they tend to linger in the release area rather than dispersing, positioning themselves in shallow waters near the bank resulting in them becoming more vulnerable to wildlife predation (Olla et al. 1998). Many piscivorous species are accused of damage in their foraging areas irrespective of whether they exploit natural ecosystems or fish farms. Thus, in practice, each species which is able to forage on fish is considered as a nuisance conflict species subjected to 
various forms of persecution (Ikeda 1952). According to fishermen, birds not only consume fish but also cause injury and stress to fish. This results in the stressed fish foraging less, growing slowly and becoming more susceptible to diseases (Carss and Marquiss 1992).

The most common avian and mammalian piscivorous species which are found in conflict with humans over fish resources in Europe include: great cormorants Phalacrocorax carbo, grey herons Ardea cinerea, European otters Lutra lutra and invasive American minks Neovison vison (Freitas et al. 2007; Kloskowski 2011). Both the great cormorant and grey heron are large, abundant and gregarious piscivorous species, frequently incriminated as pests in Europe (Dobrowolski 1995; Kushlan and Hafner 2000). In 2000-2001, in 24 European countries, 235 cases of conflict between human and great cormorants were reported on a variety of habitats and fishery types (Carrs and Marzano 2005). The great cormorants feed on different species of fish; however, in farms, they most often prey on the most abundant species (IUCN 1997; Carrs and Marzano 2005). Grey herons also cause damage to fish farms, but to a much lesser degree than the great cormorant (Dobrowolski 1995). The diet of grey herons is more varied, consisting mainly of fish, but also includes: amphibians, small mammals and insects (Cramp 1998). Fish is also a major component of the European otters diet (Jędrzejewska et al. 2001; Krawczyk et al. 2011; Juhasz et al. 2014), including species that occur most frequently at farms (Dobrowolski 1995). The American mink, still expanding its range after colonizing Europe in the 1980 s, is another important fish consumer (Brzeziński and Marzec 2003), with fish making up 40-52\% of its diet in Poland (Jędrzejewska et al. 2001; Krawczyk et al. 2013). In addition to damage caused by piscivorous animals, farmers often complain about damage from the Eurasian beaver Castor fiber, including destruction of dikes (Czech 2007).

The aim of this study was to investigate the factors affecting the presence of the most common conflict species recorded at fish ponds in western Poland. Aquaculture in Poland is part of the inland fisheries sector and is a very important part of the Polish economy, for example, in 2000-2003, >67\% of inland fisheries production came from aquaculture (FAO 2005-2015). We expect that the type of pond and method of their protection will determine the presence of the piscivorous species at farms. Specifically, we hypothesize that species will be present less frequently at farms of smaller area which are guarded or fenced and situated close to buildings. We predict that species which have the core of their distribution in the warmer temperate zone (e.g. the great egret Ardea alba) will be present more frequently in southern parts of the studied area. We expect that in areas with high variety of aquatic ecosystems (e.g. in lake districts with many natural water bodies) certain species will be less frequently present in comparison with areas with a lower number of natural water bodies where fish farms may serve as the main foraging grounds. Finally, we predict that mammals will be often present at ponds supplied by water from rivers because rivers are the natural habitat for these species used as feeding grounds and migratory routes (Zschille et al. 2012; Romanowski et al. 2011).

\section{Materials and methods}

Study area

The study area includes the western part of Poland, being a part of the Middle European Plain, the Bohemian Massif and the Polish Highland (Kondracki 2002). We divided the study area into two main areas (Fig. 1) differing in the density and size of natural water bodies: (1) the northern part (latitude $>52^{\circ} \mathrm{N}$ ) including the Baltic coast and large coastal lakes (5 with area 1000-5000 ha, 1 with area $>5000$ ha) and the South Baltic Lake Districts including two large lake districts (Pomeranian Lake District and Greater Poland Lake District) with a majority of lakes with area 100-500 ha; (2) southern part (latitude $\leq 52^{\circ} \mathrm{N}$ ) including the Middle Poland Plains (northern part), Bohemian Massif and Polish Highland (southern part), i.e. the area south of the last glaciation range with a low number of natural lakes along with some big artificial water bodies (Dobrowolski et al. 1998). More than half (67 \%) of lakes in Poland are situated in the South Baltic Coast and South Baltic Lake Districts. Only 4.1\% of Polish lakes are located in the southern part of Poland (Choiński 1995).

\section{Survey}

We conducted a telephone survey of pond fisheries in 2012-2013. We identified fish ponds using satellite 
Fig. 1 Location of the 104 fish ponds in western Poland included in the telephone survey. Grey line divides studied area into: Inorthern part (latitude $\left.>52^{\circ} \mathrm{N}\right)-$ Baltic Coast and South Baltic Lake Districts; II-southern part (latitude $\leq 52^{\circ} \mathrm{N}$ ), the Middle Poland Plains, Bohemian Massif and part of Polish Highland

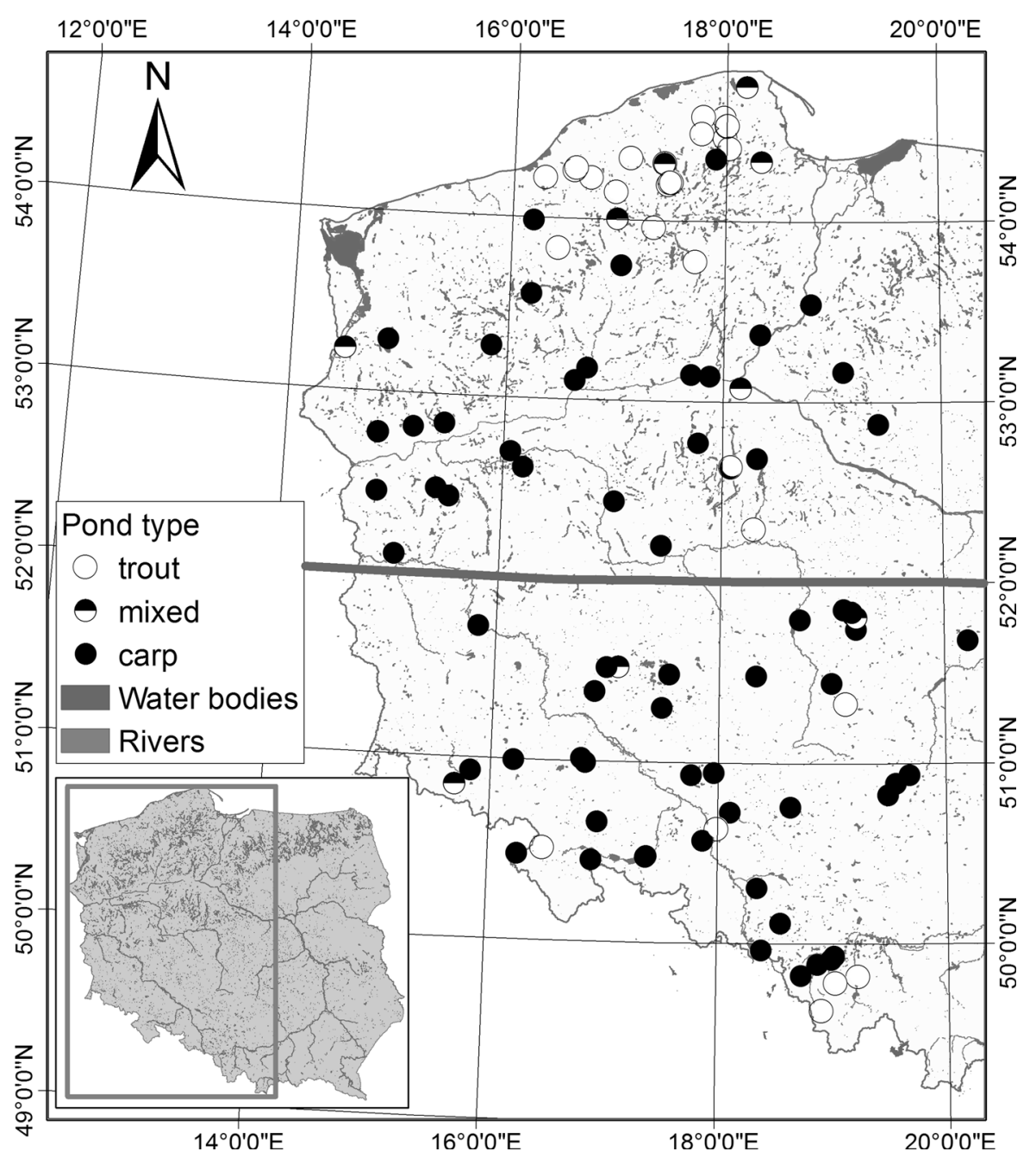

images, internet databases and telephone directories. The surveyed farms included carp, mixed and trout ponds. At carp ponds, mainly cyprinids as carp Cyprinus carpio, roach Rutilus rutilus, perch Perca fluviatilis, crucian carp Carassius carassius, Chinese carp—silver carp Hypophthalmichthys molitrix, northern pike Esox lucius, grass carp Ctenopharyngodon sp. and catfish Silurus glanis were cultivated. At trout ponds, mainly salmonids as rainbow trout $\mathrm{On}$ corhynchus mykiss, brown trout Salmo trutta, grayling Thymallus thymallus, European whitefish Coregonus lavaretus and vendace Coregonus albula were cultivated. Carp ponds are usually farms of large and stagnant water surfaces, while trout farms are usually characterized by small water surfaces and flowing water supply, concrete edges and fencing. At mixed ponds, both cyprinids and salmonids were cultivated.
In total, we surveyed 104 fish ponds of total area of 28,246 ha (Fig. 1). We asked fish farmers to list all species of animals that have visited their ponds in the last few years. Further, we collected information about pond areas (the total water surface area of fish ponds), location, source of water supply (spring, river, rainwater and lake), species of cultivated fish, and the season when the species had been observed. Telephone surveys have been found to be more effective than in-person interviews or postal surveys when questions pertain to "sensitive" issues (Brace 2004), i.e. when requested information might be viewed as incriminating (Kloskowski 2011). Biases associated with respondents' attempts to impress the interviewer (e.g. about the levels of wildlife damage) are likely to be lower than in faceto-face meetings (Brace 2004). Also, postal surveys on wildlife typically have low response rates (Carss 1994). 
Data analyses

We focused in this study on the six species (European otter, grey heron, great cormorant, great egret, Eurasian beaver and American mink) of wild vertebrates that were most frequently mentioned (in $97 \%$ of surveyed farms) by fish farmers as conflict species at their ponds. All species were observed in the water or at the pond shoreline. To define factors influencing the presence/absence of the particular conflict species at the fish ponds, we used logistic regression analysis. We coded factorial predictors (see below) using dummy coding. We analysed non-collinear predictors (Pearson's correlation coefficients for all considered, $r=10.29-0.32$ ). To select the best model determining the presence of conflict species at fish farms, we used Akaike's information criterion for small sample size $\left(\mathrm{AIC}_{\mathrm{c}}\right)$ (Burnham and Anderson 2002; Mazerolle 2006; Hegyi and Garamszegi 2011). To compare the relative performance of the models, we calculated the difference $\left(\Delta \mathrm{AIC}_{\mathrm{c}}\right)$ between the AIC value of the best model and AIC value for each of the other models and Akaike's weights (Burnham and Anderson 2002). Akaike's weights $(w)$ are the probability that a model is the best model for observed data given the candidate set of models. We considered only the models with $\Delta \mathrm{AIC}_{\mathrm{c}}<2$ (Burnham and Anderson 2002). We checked significance of the best models using Wald statistics. As the $\mathrm{AIC}_{\mathrm{c}}$ provides evidence for selection of the best model from the set, but does not permit evaluation of discriminatory performance, we used the receiver operating characteristic to assess the classification accuracy of the best models (Pearce and Ferrier 2000). We assessed predictive capability of models based on area under the receiver operating characteristic function (AUC) with value of $\geq 0.7$ for good models and $<0.7$ for poor models (Hosmer et al. 2013). Thus, we presented the best model for each species with low $\Delta \mathrm{AIC}_{\mathrm{c}}$ value and the highest AUC values. Predictors in logistic regression analyses included:

- type of pond according to main cultivated group of fish (trout, $N=28$ farms; mixed $N=10$; carp, $N=66)$;

- total pond surface area;

- latitude;

- type of water supply (river, $N=67$; rainwater, $N=17$; springs, $N=12$; lakes, $N=8$ );
- urbanization level (high-a fish farm was assumed to be situated in an urbanized habitat when at least one side of the farm ponds was directly adjacent $(<50 \mathrm{~m})$ to built-up residential area; $N=69$; low-fish farm situated farther from built-up residential area; $N=35$ );

- method of pond protection against conflict species according to information from the farmers (covering the water surface with overhead wires or lines, and fencing the fish pond with concrete and/or wire fence, $N=22$; blank firing pistols, firecrackers, hunting, $N=47$; all methods combined, $N=17$; lack of protection, $N=18$ ).

To compare frequency of the presence/absence of conflict species at ponds with different types of water supply and at farms in southern (at the latitude $\leq 52^{\circ} \mathrm{N}$; $N=29$ farms) and northern (at the latitude $>52^{\circ} \mathrm{N}$; $N=75$ ) parts of the studied area, we used $\chi^{2} /$ Fisher's exact test. To compare area of ponds with present/ absent conflict species, we used Mann-Whitney $U$ test. All statistical analyses were performed in $\mathrm{R}$ software (R Development Core Team 2007) with MuMIn (Bartoń 2013), aod (Lesnoff and Lancelot 2012) and pROC (Robin et al. 2011) packages, STATISTICA 10 (Statsoft Inc. 2011).

\section{Results}

Occurrence of conflict species

Our survey revealed that the following conflict species: European otters (at $87 \%$ of the farms), grey herons $(83 \%)$, great cormorants $(67 \%)$, great egrets (42\%), Eurasian beavers (37\%) and American minks (31\%) were recorded most frequently at fish ponds in western Poland. All species of mammals were present at ponds all year round, while all avian species were present at farms in all seasons except for winter.

All studied bird species, European otters and American minks were accused by fish farmers of damage to fish ponds (eating, injuring, and/or scaring fish-foraging on fish injured the fish and subjected them to stress). European otters often kill fish and eating away just the fish brain and the gonads. The Eurasian beaver was the only species accused of other types of damage, i.e. destruction of dykes and pond shores, blocking water inflow and/or outflow by 
building dams, and cutting down trees planted in order to strengthen the shore. Some fish farmers reported that Eurasian beaver activity caused a reduction in pond water levels, facilitating fish hunting by herons, European otters, gulls and foxes.

Factors affecting conflict species presence

The presence of the grey heron was determined by pond type (Table 1). In the case of the great cormorant, pond area was the most important factor influencing its presence/absence. Pond type and water source were the most important determinants of American mink and European otter presence/absence. For the Eurasian beaver, it was pond type and area. The great egret presence was influenced by pond type and latitude (Table 1). All analysed conflict species were reported more frequently at carp ponds compared to trout ponds or mixed ponds (Table 2). Grey herons, European otters and American minks were observed more frequently on trout ponds over mixed ponds (Table 2). Some species were present more frequently at fish farm with larger areas of ponds (Mann-Whitney $U$ test, Eurasian beaver, $Z_{64,40}=-4.76, P<0.001$; European otter, $Z_{13,91}=-2.41, P=0.02$; great cormorant, $\left.Z_{34,70}=-6.96, P<0.001\right)$. European otters and American minks were observed more frequently at ponds supplied by water from rivers (66\% and $73 \%$, respectively) compared to ponds supplied by water from other water sources (Fig. 2). Regarding latitude, great egret was recorded more frequently in the southern $(20 \%)$ than in the northern $(12 \%)$ part of the studied area $\left(\chi^{2}=4.91, P=0.03\right)$. Method of farm protection did not affect the presence of any

Table 1 Rank of the best logistic regression models of the presence/absence of conflict birds and mammals at fish ponds in western Poland based on Akaike's information criterion corrected for small sample size $\left(\mathrm{AIC}_{\mathrm{c}}\right)$

\begin{tabular}{|c|c|c|c|c|c|}
\hline Model & AIC & $\Delta \mathrm{AIC}_{\mathrm{c}}$ & $\begin{array}{l}\text { Akaike's } \\
\text { weights }(w)\end{array}$ & AUC & Wald test $P$ \\
\hline \multicolumn{6}{|l|}{ American mink } \\
\hline Int + pond type - longitude & 134.0 & 0.00 & 0.29 & 0.65 & 0.004 \\
\hline- Int + pond type - water source & 134.1 & 0.16 & 0.26 & 0.67 & 0.01 \\
\hline- Int + pond type & 135.4 & 1.46 & 0.14 & 0.35 & 0.008 \\
\hline \multicolumn{6}{|l|}{ Eurasian beaver } \\
\hline- Int + pond type + pond area & 124.7 & 0.00 & 0.38 & 0.76 & $<0.001$ \\
\hline- Int + pond type & 125.9 & 1.15 & 0.21 & 0.70 & 0.001 \\
\hline \multicolumn{6}{|l|}{ European otter } \\
\hline Int + pond area - water source & 78.0 & 0.00 & 0.13 & 0.71 & $<0.001$ \\
\hline Int - water source & 78.6 & 0.59 & 0.10 & 0.39 & $<0.001$ \\
\hline Int + pond type - water source & 78.7 & 0.71 & 0.10 & 0.69 & $<0.001$ \\
\hline Int + pond area & 79.3 & 1.31 & 0.07 & 0.70 & $<0.001$ \\
\hline Int + pond area + pond type & 79.3 & 1.31 & 0.07 & 0.70 & $<0.001$ \\
\hline Int + pond type & 79.6 & 1.61 & 0.06 & 0.66 & $<0.001$ \\
\hline \multicolumn{6}{|l|}{ Great cormorant } \\
\hline Int + pond area - longitude & 69.8 & 0.00 & 0.30 & 0.80 & 0.002 \\
\hline Int + pond area & 70.4 & 0.56 & 0.23 & 0.92 & $<0.001$ \\
\hline \multicolumn{6}{|l|}{ Great egret } \\
\hline Int + pond type - latitude & 113.8 & 0.00 & 0.09 & 0.75 & 0.001 \\
\hline \multicolumn{6}{|l|}{ Grey heron } \\
\hline- Int + pond type + pond area & 91.9 & 0.00 & 0.26 & 0.70 & $<0.001$ \\
\hline- Int + pond type & 91.4 & 0.51 & 0.20 & 0.67 & $<0.001$ \\
\hline
\end{tabular}

Akaike's weights $(w)$ are calculated from the full set of models. The predictive capability of functions based on area under the receiver operating characteristic function (AUC); good models (AUC $\geq 0.7$ ) bolded. Model significance estimated by Wald test; Int intercept 
Table 2 Frequency of occurrence of conflict species at various types of ponds

\begin{tabular}{llll}
\hline Species $(N)$ & \multicolumn{3}{l}{ Type of pond } \\
\cline { 2 - 4 } & Carp (\%) & Trout (\%) & Mixed (\%) \\
\hline European otter (91) & $68^{\mathrm{a}, \mathrm{f}}$ & $22^{\mathrm{a}}$ & $10^{\mathrm{f}}$ \\
Grey heron (87) & $69^{\mathrm{a}, \mathrm{b}}$ & $23^{\mathrm{a}, \mathrm{f}}$ & $8^{\mathrm{b}, \mathrm{f}}$ \\
Great cormorant (70) & $79^{\mathrm{a}, \mathrm{b}}$ & $10^{\mathrm{a}}$ & $11^{\mathrm{b}}$ \\
Great egret (33) & $94^{\mathrm{c}, \mathrm{d}}$ & $0^{\mathrm{c}}$ & $6^{\mathrm{d}}$ \\
Eurasian beaver (39) & $90^{\mathrm{a}, \mathrm{c}}$ & $5^{\mathrm{a}}$ & $5^{\mathrm{c}}$ \\
American mink (44) & $80^{\mathrm{c}, \mathrm{d}}$ & $18^{\mathrm{c}, \mathrm{e}}$ & $2^{\mathrm{d}, \mathrm{e}}$ \\
\hline
\end{tabular}

Comparisons among types of ponds

$\chi^{2} 2 \times 2$ tests: $^{\mathrm{a}, \mathrm{b}} P<0.001$

Fisher's exact test: ${ }^{\mathrm{c}, \mathrm{d}, \mathrm{e}} P<0.001,{ }^{\mathrm{f}} P=0.03$

conflict species at surveyed ponds. The urbanization level (the distance from the fish farms to the nearest building) did not affect the presence of any studied conflict species at surveyed fish farms.

\section{Discussion}

Great cormorants, European otters, grey herons, Eurasian beavers, great egrets and American minks were the most common species reported by surveyed fish farmers in western Poland. All these species were also often present at fish ponds in eastern Poland in 2003-2004. Specifically, European otters and grey herons were observed up to $>94 \%$ of surveyed farms (Kloskowski 2011). In contrast, in our study, the European otters were observed at $87 \%$ surveyed ponds, while the grey heron is at $83 \%$. Less frequent presence of these species at farms in western Poland compared to eastern Poland may be explained in terms of more uniform distribution of natural water bodies in the northern Poland (Dobrowolski 1995). In the eastern part of Poland, large lakes are located only in the north (the Masurian Lake District). Thus, in western Poland, piscivores could have exploited numerous natural aquatic habitats and were less often recorded at fish farms. Grey herons and great cormorants are commonly perceived as two of the main predators of fish stocks at fish farms in other European countries (Dobrowolski 1995). These two species were the most persecuted and killed at fish ponds in southern Poland (Wiehle and Bonczar 2007). The European otter was often present at fish ponds in Czech Republic (Adámek et al. 2003), Austria (Bodner 1995) and Portugal (Trindade 1991). This species prefers habitats such as rivers, lakes and fish farms (Durbin 1998; Romanowski 2006). In Poland, the presence of European otters at fish ponds increased from $62 \%$ in 1989-1990 to $94 \%$ in 2011 (Romanowski et al. 2011). Fish ponds may be crucial for maintaining the population of European otters during very cold winters when the natural waterways freeze (Kloskowski 2005). Fish ponds may also be accessed by American minks in winter when many natural water bodies and rivers are covered with ice and they are unable to access their usual source of prey (Zschille et al. 2012). In the 1990s, this species was only found in northern Poland; however, it is now found across Poland (Brzeziński and Marzec 2003). The fish ponds have shallow warm water, which provides ideal conditions for the growth of aquatic vegetation, which is an important component of the
Fig. 2 The frequency of occurrence of European otters and American minks at ponds with different type of water supply.

Comparisons among types of ponds and water supplies:

$\chi^{2} 2 \times 2$ tests: $a, b, c$

$P<0.001, d P=0.01$;

Fisher's exact test:

$e, f P<0.001, g P=0.02$

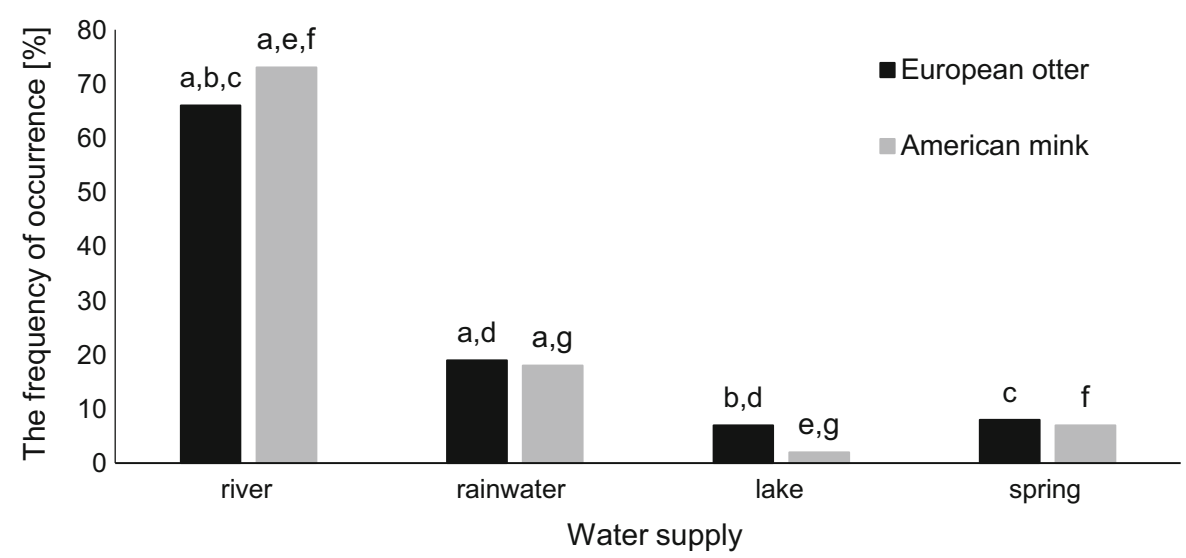


European beaver's diet (Czech 2007). Fish ponds are often surrounded by dikes (Dobrowolski 1995), in which beavers regularly dig dens with no need of building lodges (Czech 2007). Mammals such as Eurasian beaver, European otter and American mink are consistently present at farms throughout the year. The ice cover on the ponds does not deter these species due to their ability to continue to forage below the ice (Czech 2007; Kloskowski 2005; Sales-Luís et al. 2009). The presence of avian piscivores may be increased if they breed close to the farm (Dobrowolski 1995) and further increased if there are no alternate natural foraging grounds nearby. The increased number of piscivorous birds present at fish ponds has been observed during the breeding season (elevated energy requirements during reproduction) and also during spring and autumn migration (using fish farms as stopover sites) and in winter (wintering quarter). In the surveyed ponds, all studied avian species were observed in spring, summer and winter.

The pond type and the area of ponds influenced the presence of the conflict species at the surveyed fish farms. Larger ponds were characterized by both longer shoreline which offered larger shallow water zones accessible for wading birds and greater area of open water surface accessible for diving piscivores. All conflict species were most frequently observed on carp ponds which are often characterized by abundant food supplies with a higher density of fish than in the natural water bodies (Dobrowolski 1995; Billard 1999). Carp ponds are shallow, making the fish easy to catch, especially for grey herons and great egrets as their anatomical structure restricts foraging mainly to shallow water zones (Marion 1989; Cramp 1998). On carp ponds, great cormorants and other piscivorous birds forage mainly on carp (Mellin et al. 1997). Furthermore, carp ponds, which usually cover large areas, are rarely fenced due to the costs associated with this, resulting in easy access to this type of farm for wildlife. The trout and mixed farms usually cover a smaller area and are better protected against piscivores compared to carp ponds due to the presence of fences and overhead wires or lines and/or the presence of guard dogs (FAO 2005-2015). However, our analyses showed that the protection measure did not determine the presence of conflict species at fish ponds. It has been reported that great cormorants and grey herons may become accustomed to the methods employed such as fencing (Cowx 2013), indicating that current measures may not be effective. In contrast to our predictions, the proximity of buildings did not determine the presence of conflict species at fish ponds. Most likely, these species adapted to habituate human presence and various forms of pond protection (Spanier 1979; Salmon and Conte 1982). Killing birds within proximity of ponds is not considered effective as the birds are quickly replaced by others (Draulans and van Vessem 1985). The area covered by ponds did not significantly affect the presence/absence of American mink, great egret and grey heron. Wading birds, herons and egrets only forage in shallow water zones close to the shore; thus, the configuration of ponds (type of shoreline, depth) is more important than the area. The high fish density and the easy access to prey attract the American mink, regardless of the size of the pond.

Water source influenced the presence of both European otters and American minks at the surveyed ponds. They were mostly reported at farms supplied by river water. Movements along river networks facilitate finding this type of ponds (Romanowski et al. 2011). Moreover, this type of pond gives both species the opportunity to enter the farms imperceptibly with no need to exit the water (Sales-Luís et al. 2009). Poorly protected or unprotected outlets and inlets give these mammals a higher chance of entering farms (Romanowski et al. 2011).

Latitude has been recognized as another significant factor determining the presence of great egrets. This species was reported more frequently at farms in the southern part of the studied area, also matching its present distribution in Poland (Sikora et al. 2007). In recent years, the number of breeding sites of this species has increased in Poland, especially in central, south-eastern and north-eastern parts of the country (Ławicki 2014; Sikora and Cząstkiewicz 2014). Nonbreeding and wintering populations have increased in line with the expanding breeding population. Currently, the winter population in Poland is estimated at $>1500$ birds (Eawicki 2014). The population of the great egret has grown spectacularly throughout Europe in the last 30 years. Given the continued northwards range expansion of this species (Eawicki 2014), knowledge of its occurrence at fish ponds will aid in understanding its exploitation of newly colonized landscapes.

Wildlife surveys performed by respondents who are not wildlife professionals may generate incorrect 
species identification. However, a field verification of otter observations at aquaculture facilities indicated that professional fish farmers were able to correctly identify visiting vertebrates (Kloskowski 2005). Moreover, fish farmers responding to our study often described features of particular species observed.

In conclusion, our study revealed that the presence of the six most frequently reported avian and mammalian species in western Poland was determined by the pond type and/or area. The presence of both piscivorous mammals was determined by ponds supplied by river water. Latitude affected occurrence of great egrets (more frequent in the south). Regular surveys of species occurring at fish farms may assist in monitoring of invasive species, or increases in the species range. Increasing populations of invasive American mink in Europe have a negative impact on aquatic ecosystems due to the reduction in the population size of birds and mammals (Halliwell and Macdonald 1996; Brzeziński and Marzec 2003). Data collected in our study concerning the presence of piscivores at fish ponds may serve as a base for more comprehensive studies investigating the actual impact of those species on fish farming as well as for experimental studies on the effectiveness of various mitigation measures. Future studies could also include assessment of economic losses attributed to particular species and the effectiveness of various measures (both lethal and non-lethal) for reducing or minimizing damage to fish farms.

Acknowledgments We are grateful for volunteer participation of the fish farmers in the survey. We appreciate the improvements in English usage made by Madeleine Stigner. We would like to thank anonymous Reviewers for critical comments on earlier versions of the manuscript.

\section{References}

Adámek Z, Kortan D, Lepič P, Andreji J (2003) Impacts of otter (Lutra lutra L.) predation on fishponds: a study of fish remains at ponds in the Czech Republic. Aquacult Int 11:389-396

Bartoń K (2013) MuMIn: multi-model inference. R package version 1.10.0. http://CRAN.R-project.org/package=MuMIn

Billard R (1999) Carp: biology and culture. Springer, Berlin

Bodner M (1995) Fish loss in Austrian fish-ponds as a result of otter (Lutra lutra L.) predation. IUCN Otter Spec Group Bull 12:3-10

Brace I (2004) Questionnaire design. How to plan, structure and write survey material for effective market research. Kogan Page, London
Brzeziński M, Marzec M (2003) The origin, dispersal and distribution of the American mink Mustela vison in Poland. Acta Theriol 48:505-514

Burnham KP, Anderson DR (2002) Model selection and multimodel inference: a practical information-theoretic approach. Springer, New York

Carss DN (1994) Killing of piscivorous birds at Scottish in fish farms, 1984-87. Biol Conserv 68:181-188

Carss DN, Marquiss M (1992) Avian predation at farmed and natural fisheries. In: Lucas MC, Diack I, Laird L (eds) Interactions between fisheries ant the environment. Proceedings of the institute of fisheries management. 22nd annual study course, University of Aberdeen, UK, pp 179-196, 10-12 Sept 1991

Carrs DN, Marzano M (2005) Reducing the conflict between cormorants and fisheries on a pan-European scale. REDCAFE—summary and national overviews. Report to the European Commission. pp 1-386

Choiński A (1995) Zarys limnologii fizycznej Polski. Wyd Naukowe UAM, Poznań

Cowx IG (2013) Between fisheries and bird conservation: the cormorant conflict. European Parliament. Policy department structural and cohesion policies, Brussels. Publications Office. pp 1-68

Cramp S (1998) The complete birds of the Western Palearctic. CD-ROM. Oxford University Press, Oxford

Curtis KS, Pitt WC, Conover MR (1996) Overview of techniques for reducing bird predation at aquaculture facilities. All archived publications. Paper 1011. http://digitalcommons. usu.edu/extension_histall/1011. Accessed 20 Oct 2015

Czech A (2007) Bóbr europejski (Castor fiber). Krajowy Plan Ochrony gatunku. Opracowanie planów renaturalizacji siedlisk przyrodniczych i siedlisk gatunków na obszarach Natura 2000 oraz planów zarządzania dla wybranych gatunków objętych Dyrektywą Ptasią i Dyrektywą Siedliskową. PL/IB/2001EN/02, Kraków, pp 1-46. http://www. bobry.pl/docs/bobr_beaver.pdf. Accessed 20 Jan 2015

Development Core Team R (2007) R: a language and environment for statistical computing. R Foundation for Statistical Computing, Vienna. ISBN 3-900051-07-0

Dobrowolski K (1995) Environmental-economic evaluation of fish ponds in Poland. IUCN Poland, Warszawa

Dobrowolski K, Halba R, Lewandowski K (1998) Przegląd środowisk wodnych i błotnych. In: Dobrowolski K, Lewandowski K (eds) Ochrona środowisk wodnych i błotnych w Polsce. Oficyna Wyd Inst Ekol PAN, Dziekanów Leśny

Draulans D, Van Vessem J (1985) Age-related differences in the use of time and space by radio-tagged grey herons in winter. J Anim Ecol 54:771-780

Durbin LS (1998) Habitat selection by five otters Lutra lutra in rivers of northern Scotland. J Zool 245:85-92

FAO (2005-2015) National aquaculture sector overview. poland. national sector overview fact sheets. Text by Zakes $\mathrm{Z}$. In: FAO fisheries and aquaculture department. Rome. http://www.fao.org/fishery/countrysector/naso_poland/en. Accessed 25 July 2015

Freitas D, Gomes J, Sales-Luís T, Madruga L, Marques C, Baptista G, Rosalino LM, Antunes P, Santos R, SantosReis M (2007) Otters and fish farms in the Sado estuary: ecological and socioeconomic basis of a conflict. Hydrobiologia 587:51-62 
Halliwell EC, Macdonald DW (1996) American mink Mustela vison in the upper Thames catchment: relationship with selected prey species and den availability. Biol Conserv 76:51-56

Hegyi G, Garamszegi LZ (2011) Using information theory as a substitute for stepwise regression in ecology and behavior. Behav Ecol Sociobiol 65:69-76

Hosmer DW, Lemeshow S, Sturdivant RX (2013) Applied logistic regression. John Wiley \& Sons, Hoboken

Ikeda S (1952) Investigations on the relation of wild birds to the industry in Japan. Inst Ornithol Mammal Rep 13:1-114

IUCN (1997) Fishing for a living-the ecology and economics of fishponds in central Europe. IUCN, Gland, Switzer Cambridge, UK

Jędrzejewska B, Sidorovich VE, Pikulik MM, Jędrzejewski W (2001) Feeding habits of the otter and the American mink in Białowieża Primeval forest (Poland) compared to other Eurasian population. Ecography 24:165-180

Juhasz K, Vegvari Z, Perpek M, Lukacs BA, Nagy SA (2014) Main versus alternative prey of Eurasian otters in an eastEuropean artificial wetland system. North West J Zool 10:1-9

Kloskowski J (2005) Otter Lutra lutra damage at farmed fisheries in southeastern Poland, I: an interview survey. Wildl Biol 11:201-206

Kloskowski J (2011) Human-wildlife conflicts at pond fisheries in eastern Poland: perceptions and management of wildlife damage. Eur J Wildl Res 57:295-304

Kondracki J (2002) Geografia regionalna Polski Wyd 3. Wyd Naukowe PWN, Warszawa

Krawczyk AJ, Skierczyński M, Tryjanowski P (2011) Diet of the Eurasian otter Lutra lutra on small watercourses in Western Poland. Mammalia 75:207-210

Krawczyk AJ, Bogdziewicz M, Czyż MJ (2013) Diet of the American mink Neovison vison in an agricultural landscape in western Poland. Folia Zool 64:303-309

Kushlan JA, Hafner H (2000) Heron conservation. Academic, San Diego

Ławicki $Ł$ (2014) The Great White Egret in Europe: population increase and range expansion since 1980. Br Birds 107:8-25

Lesnoff M, Lancelot R (2012) aod: analysis of overdispersed data. $\mathrm{R}$ package version 1.3. http://cran.r-project.org/ package $=$ aod

Littauer G (1990) Avian predators: frightening techniques for reducing bird damage at aquaculture facilities. SRAC publication (USA)
Marion L (1989) Territorial feeding and colonial breeding are not mutually exclusive: the case of the grey heron (Ardea cinerea). J Anim Ecol 58:693-710

Mazerolle MJ (2006) Improving data analysis in herpetology: using Akaike's information criterion (AIC) to assess the strength of biological hypotheses. Amphib Reptil 27:169-180

Mellin M, Mirowska-Ibron I, Gromadzka J, Krupa R (1997) Recent development of the Cormorant breeding population in north-eastern Poland. Suppl Ric Biol Selvaggina 26:89-95

Olla BL, Davis MW, Ryer CH (1998) Understanding how the hatchery environment represses or promotes the development of behavioral survival skills. Bull Mar Sci 62:531-550

Pearce JL, Ferrier S (2000) Evaluating the predictive performance of habitat models developed using logistic regression. Ecol Model 133:225-245

Robin X, Turck N, Hainard A, Tiberti N, Lisacek F, Sanchez J-C, Müller M (2011) PROC: an open-source package for R and $\mathrm{S}+$ to analyze and compare ROC curves. BMC Bioinform 12:1-8

Romanowski J (2006) Monitoring the otter recolonisation of Poland. Hystrix It J Mammal 17:37-46

Romanowski J, Orłowska L, Zając T (2011) Program ochrony wydry Lutra lutra w Polsce. Krajowa strategia gospodarowania wydrą. SGGW, Warszawa

Sales-Luís T, Freitas D, Santos-Reis M (2009) Key landscape factors for Eurasian otter Lutra lutra visiting rates and fish loss in estuarine fish farms. Eur J Wildl Res 55:345-355

Salmon TP, Conte FS (1982) Control of bird damage at aquaculture facilities. US Fish Wildl Serv 475:12

Sikora A, Cząstkiewicz D (2014) Ekspansja czapli białej Ardea alba na Warmii i Mazurach. Orn Pol 55:264-278

Sikora A, Rohde Z, Gromadzki M, Neubauer G, Chylarecki P (2007) Atlas rozmieszczenia ptaków lęgowych Polski 1985-2004. Bogucki Wyd Naukowe, Poznań

Spanier E (1979) Experiments in repelling night herons from fish ponds by the use of distress calls. Bamidgeh 31:11-24

StatSoft Inc. (2011) STATISTICA (data analysis software system), version 10. www.statsoft.com

Trindade A (1991) Fish farming and otters in Portugal IUCN otter spec. Group Bull 6:7-9

Wiehle D, Bonczar Z (2007) Śmiertelność ptaków w warunkach stawów rybnych. Not Ornitol 48:163-173

Zschille J, Stier N, Roth M, Berger U (2012) Dynamics in space use of American mink (Neovison vison) in a fishpond area in Northern Germany. Eur J Wildl Res 58:955-968 